\title{
New Challenges for Litigation in THE ELECTRONIC AGE
}

\author{
SHERYL JACKSON ${ }^{*}$
}

[Australian courts are already dealing with issues around electronic documents and technology in the pre-trial and trial stages of litigation, in particular in cases involving large volumes of documentation. However issues surrounding the ease with which such documents can be disseminated have troubled the courts. The adoption of new technology is gathering pace, but the courts are proceeding with caution.]

\section{INTRODUCTION}

In matters involving large volumes of documents which must be gathered, sorted, indexed and classified it has been common for some time for litigation practitioners to use information technology as an aid in document management.

More recently the benefits of technology for the conduct of a trial have become apparent. A number of courtrooms have been set up in Australia, either as permanent "electronic courts", or for the conduct of particular large scale litigation.

\footnotetext{
* Associate Professor, Faculty of Law, Queensland University of Technology.

${ }^{1}$ There is no clear definition of what is encompassed by the term "electronic court" as there is an almost endless range of features which are possible. A number of features are now part of the expected armoury of a fully equipped "electronic court". These features are considered at IV below.
} 
The Victorian Supreme Court can boast its $13^{\text {th }}$ court - one of the world's most modern courtrooms, specially equipped in 1999 for high-tech cases. ${ }^{2}$ Although some major cases have been conducted in that court using worldleading technology, it was revealed at the time of release of that court's then new Practice Note in $2002^{3}$ that as at that date such cases had involved less than one percent of the legal profession. ${ }^{4}$

The position in New South Wales has been similar, with technology used in some of the Royal Commissions of Inquiry, as for example the Special Commission of Inquiry into the Glenbrook Rail Accident (Glenbrook Inquiry) and the Special Commission of Inquiry into the Waterfall Rail Accident (McInerney Inquiry) although in real terms it is still the case that a very limited number of hearings have been conducted electronically.

As the benefits that technology can bring to large scale litigation have become apparent to the courts they have one by one been introducing practice notes on the use of information technology in appropriate cases both during discovery and at trial. These practice notes "encourage", rather than mandate, the use of technology pre-trial and at trial. In most of the matters which have proceeded to trial electronically this has been with the agreement and cooperation of the parties and their representatives. It is now clear, however, that in appropriate cases and despite opposition from one or more of the parties involved, the courts will direct that technology be used at trial. ${ }^{5}$

The purpose of this article is to consider in the light of the recent decisions the role that technology may play in the litigation process and a range of associated legal issues which will undoubtedly require further exploration as technology becomes increasingly integrated into everyday litigation practice.

${ }^{2}$ Prue Innes (Courts Information Officer), "Restored Supreme Court uses Latest Court Technology", Supreme Court of Victoria Media Release, 11.10.99. http://www.supremecourt.vic.gov.au/CA256902000FE154/Lookup/MediaReleases/\$ file/Media-Latest \%20Court\%20Technology.pdf

${ }^{3}$ Practice Note No 1 of 2002, Guidelines for the use of Technology in any Civil Matter, published 29.4.02. See now Practice Note No 1 of 2007, Guidelines for the Use of Technology in any Civil Litigation Matter.

${ }^{4}$ Prue Innes (Courts Information Officer), "Technology in Court expands at Supreme Court", Supreme Court Supreme Court of Victoria Media Release, 20.5.2002 at http://www.supremecourt.vic.gov.au/CA256902000FE154/Lookup/MediaReleases/\$ file/Media-TechnologyinCourt.pdf, accessed 20.08.07.

${ }^{5}$ Idoport Pty Ltd v National Australia Bank Limited [6] [2000] NSWSC 338; Harris Scarfe v Ernst \& Young (No 3) [2005] SASC 407. 


\section{Practice Notes - The Australian LANDSCAPE}

The Supreme Court of New South Wales published Practice Note No 105 Use of Technology in Civil Litigation in March 1999. That set the scene for the use of technology as an everyday tool in civil litigation in New South Wales. The New South Wales Note was used to some extent as a starting point for other jurisdictions although there are significant variations across jurisdictions. The note has been replaced several times since ${ }^{6}$, with the current note being Practice Note No SC Gen 7 Supreme Court - Use of Technology, which commenced on 1 September 2006.

In Victoria, Practice Note 3 of 1999 was issued in April 1999. Following review of that Note, a new Practice Note, No 1 of 2002 Guidelines for the use of Technology in any Civil Matter, was published on 29 April 2002. ${ }^{7}$ That note was in turn replaced by the Current Practice Note, No 1 of 2007 Guidelines for the Use of Technology in any Civil Litigation Matter, issued on 8 February 2007.

The Federal Court of Australia published Practice Note 17 Guidelines for the Use of Technology in Litigation in any Civil Matter in April 2000. This Note remains current, but the Federal Court is in the process of preparing a "Judicial Toolkit" as a key component of its eTrial strategy. The Toolkit will include a replacement for the current Practice Note. ${ }^{8}$

For South Australia Practice Direction No 52 Guidelines for the use of technology in litigation in any civil matter was issued on 17 August 2001.

\footnotetext{
${ }^{6}$ Practice Note No 105 Use of Technology in Civil Litigation was replaced by Practice Note No 127 Use of Technology in Civil Litigation, with effect from 1 March 2004. This was replaced by SC Gen 7 Supreme Court - Use of Technology, with effect from 17 August 2005. This was in turn replaced by Practice Note SC Gen 7 which was published on 15 August 2006 and commenced on 1 September 2006.

${ }^{7}$ The review was conducted by the Victorian Society for Computers and the Law (headed by Sandra Potter and Phil Farrelly as co-chairs of the Society's Practice and Procedures Focus Group) on behalf of the court: Sandra Potter and Peter Moon, "Supreme Court of Victoria Practice Note 1 of 2002- Guidelines for the use of technology in civil matters", (2002) 49 NSW Society for Computers and the Law Journal, at:http://www.nswscl.org.au/journal/49/Potter_Moon.html, accessed 10.8.07.

${ }^{8}$ The Hon MEJ Black AC, Chief Justice of the Federal Court of Australia, "New Technology Developments in the Courts: Usages, Trends and Recent Developments in Australia", paper presented at the Seventh Worldwide Common Law Judiciary Conference, May 2007 at 17-18.
} 
The note was based on the generic draft practice note issued by the Australian Institute of Judicial Administration in 1999. ${ }^{9}$ This practice direction applied to civil litigation in all South Australian courts. ${ }^{10}$ Practice Direction 2.1 of Supreme Court Practice Directions 2006 (SA) Guidelines for the Use of Electronic Technology applies on and after 4 September 2006 and to actions which are governed by the Supreme Court Civil Rules 2006 (SA).

The Northern Territory issued Practice Direction No 2 of $2002^{11}$ "Guidelines for the use of technology in any civil matter" on 13 February 2002.

Queensland followed the lead of the other states, with the issue by the Supreme Court of Queensland on 13 July 2004 of Practice Direction No 8 of 2004: Electronic Management of Documents.

There are no relevant Practice Directions in Western Australia, Tasmania or the ACT.

The detail of the various practice notes or directions varies, but those in the Federal Court, New South Wales, the Northern Territory, South Australia and Victoria are similar in many respects. They each encourage parties to use electronic data (or databases) to create lists of their discoverable documents, encourage parties to exchange electronic versions of documents such as pleadings and statements, ${ }^{12}$ and encourage parties to give discovery by exchanging databases created in accordance with an agreed protocol. They also encourage parties to consider the use of technology, including an electronic court book, at trial.

${ }^{9}$ http://www.aija.org.au/info/techn/guideciv.htm

${ }^{10}$ The Practice Direction stood as Supreme Court Practice Direction 52, District Court Practice Direction No 10, and Magistrates Court Practice Direction No 1 of 2001.

11 The Practice Direction can be accessed at: http://www.nt.gov.au/ntsc/documents/20060106NT_SupremeCourt\%20PracticeDirec tions.pdf

${ }^{12}$ In the Federal Court, New South Wales and the Northern Territory, parties are required to accede to reasonable requests for copies of court documents in electronic format. The Victorian Note specifies (at 5.5) that "a party must, unless the Court otherwise orders, upon request deliver to any other party an additional copy in electronic format in accordance with the default standard of any court document which is required to be delivered in hard copy." The Practice Direction in South Australia states (at 2.1.15) that when a party is required to serve a document in hard copy on another party, that party must, on the request of the receiving party, provide an electronic copy of that document." 
The Practice Direction in Queensland has many features that are clearly modelled on those applying elsewhere but it is certainly more conservative in its approach, and less demanding. Its stated aim is to "streamline the management of disclosed documents" by encouraging the adoption of document protocols from the institution of proceedings ${ }^{13}$, and encouraging the use of information technology to manage documents for disclosure and for interlocutory and directions hearings and at trial.

The significant limitation that exists in relation to the current Australian Practice Notes and Directions in each of the jurisdictions other than Victoria is that they do not cover electronic discovery issues per se because they do not cater for the discovery of electronic documents in their native electronic format, such as email and their attachments, and electronic documents found on hard disks. There are a range of issues associated with sourcing documents in native electronic format, particularly those to be found on backup tapes. ${ }^{14}$ Rather than deal with these issues, the notes tend to deal only with the conversion of hard copy documents to an electronic format ie the electronic information to which they refer generally relates to paper documents that have been scanned and the meta-data used to describe certain details about the document, for instance, document type (eg letter, contract etc), the document date and the document author. Parties are required to print electronic documents onto paper, scan the printed documents into a digitized format, index the scanned documents in a database system and exchange the scanned documents with supporting meta-data to the other litigants and the court.

When electronic documents are to be included in discovery, it has been appropriately suggested that parties should discuss an electronic discovery plan and potential issues associated with electronic documents, including such issues as: whether any preservation measures are required, the media for production of electronic data and documents, the possibility of deleted data and the recovery of such data, the scope of email discovery, and the privilege that may attach to inadvertent production of electronic data. ${ }^{15}$

\footnotetext{
${ }^{13}$ The Queensland Practice Direction relies heavily on form 19 (list of documents) of the forms under the Uniform Civil Procedure Rules 1999 (Qld), which effectively provides a "default" protocol "for use in all cases." (The Practice Direction amended the previously existing version of the form to manage this).

${ }^{14}$ See BT Australasia Pty Ltd $v$ State of New South Wales [1998] FCA 363.

${ }^{15}$ A. Stanfield, E-Litigation, Thompson Legal and Regulatory Group, 2003 at 49-50.
} 
The recent Practice Note in Victoria is the first in Australia to formally recognise the distinction between paper and electronic data and to attempt to address some of the associated issues. It provides "a court approved framework and default standard for managing both hard copy and electronic documents. "16 The Federal Court is also in the process of developing a new practice direction which deals with the disclosure of documents in their native electronic format ${ }^{17}$, although the proposed practice direction has not yet been released.

Other countries have developed electronic discovery protocols that provide guidelines on discovering electronic information first-hand, in their native electronic formats. On 12 April 2006 amendments to the US Federal Rules of Civil Procedure were approved by the United States Supreme Court. The amendments took effect on 1 December 2006 and deal with "electronically stored information." ${ }^{\prime 18}$ In Canada, the Supreme Court of British Columbia has created an Electronic Evidence Practice Direction ${ }^{19}$ and the Ontario Bar Association Discovery Task Force has issued eDiscovery Guidelines ${ }^{20}$. The UK has developed a Draft Practice Direction - the Use of Technology in Civil

${ }^{16}$ Practice Note No 1 of 2007, Guidelines for the Use of Technology in any Civil Litigation Matter, at 1.1. The Practice Note also provides (at 1.5) advice that further information to be found on the Supreme Court website includes guidance about the collection and management of electronic material in litigation.

${ }^{17}$ Above, $\mathrm{n} 8$.

${ }^{18}$ The amendments affected rules 16, 26, 33, 34, 37, 45 and form 35. The Federal Rules of Civil Procedure can be accessed via the U.S. Courts website at: http.//www.uscourts.gov/rules/newrules4.html. Instrumental to the development of these amendments was the Sedona Conference, a non-profit organisation of litigation practitioners in the USA, which produced a report entitled: "The Sedona Principles Addressing Electronic Document Production" (July 2005 Version) at: http://www.thesedonaconference.org/dltForm?did=7_05TSP.pdf, accessed 20.8.07.

${ }^{19}$ Supreme Court of British Columbia, Practice Direction Re Electronic Evidence, published 1.7.06.

${ }^{20}$ Ontario Bar Association, Discovery Task Force Sub-Committee, "Electronic Discovery Guidelines", 2004. at http://www.oba.org/en/pdf_newsletter/EDiscoveryGuidelines.pdf, accessed 10.8.07. 
Proceedings ${ }^{21}$, which provides very prescriptive examples of how to manage and exchange electronic documents.

\section{Technology at Trial - Can the Court Direct the Use OF AN ELECTRONIC COURTROOM?}

In most of the matters that have been conducted with the use of technology at trial, the use of the technology has been by agreement between the parties. The decisions in Idoport Pty Ltd $v$ National Australia Bank Limited [6] ${ }^{23}$ ("Idoport") and Harris Scarfe v Ernst \& Young (No 3) ${ }^{24}$ ("Harris Scarfe") have made it clear that in appropriate cases and despite opposition by one or more of the parties the court will direct that technology be used at trial and make associated orders as necessary to facilitate the conduct of an electronic trial.

\section{A Idoport Pty Ltd v National Australia Bank Limited - The Facts}

In Idoport Pty Ltd v National Australia Bank Limited [6] ${ }^{25}$ ("Idoport") the proceedings involved complex claims by the plaintiffs extending to claims for billions of dollars against defendants including the National Australia Bank $^{26}$. The defendants estimated the time required for the final hearing in the proceeding would be one year although it was accepted that it was impossible to give in any conclusive way an accurate estimate of the precise length of the hearing. There were approximately 8 weeks remaining before the hearing was to commence.

21 http://www.listgroup.org/documents/IT\%20Practice\%20Direction\%20080705.doc , accessed 10.8.07. See also the Litigation Support Technology Group, UK, "Data Exchange Protocol Part 1 of 2 (Disclosure Documents) and Part 2 of 2 (Disclosure of Data), 27.4.2007 accessible on the Litigation Support Technology Group Website at http://www.listgroup.org/publications.htm.

22 Sedona Conference Working Party, "The Sedona Guidelines: Best Practice Guidelines \& Commentary for Managing Information \& Records in the Electronic Age", 2005, at: http://www.thesedonaconference.org/content/miscFiles/TSG9_05.pdf ${ }^{23}$ [2000] NSWSC 338.

${ }^{24}$ [2005] SASC 407.

${ }^{25}$ [2000] NSWSC 338.

${ }^{26}$ The exact nature of the claims is summarised in the judgment on an interlocutory hearing delivered on 19 August 1999: Idoport Pty Ltd v National Australia Bank Limited [1] [1999] NSWSC 828 at para 309 and following. 
The proceedings involved very large numbers of documents. It was clear that in excess of 100,000 relevant pages of materials would arguably be referred to, relied upon or tendered for the defendant. The defendants had substantially imaged discovered documents but had not imaged documents relied upon or seen by experts, documents produced on subpoena, or documents discovered by the plaintiffs and which the defendants may decide to tender. From the plaintiffs' side of the record, it appeared the trial may have to cope with 20,000 to 25,000 pages.

The primary question for determination by the court was the extent to which technology should be used for the hearing of the proceedings. The defendants did not wish to use the Technology Court. Although in principle embracing the use of technology where appropriate to assist the parties and the Court to dispose of the proceedings as quickly and efficiently as possible, it was their submission that the use of that court would not be efficient for the particular proceedings at hand. The plaintiffs on the other hand sought to use the Technology Court. They submitted that this use would be an efficient way of seeking to get through the hearing in a practicable way with the minimum of time, consistent with the obvious requirement that all parties be permitted to take time and care with which to present their respective cases.

The decision of Einstein $\mathrm{J}$ involved detailed analysis of the basis of the court's jurisdiction to direct the use of the Technology Court and discussion of the manner in which the trial might proceed if conducted in that court.

\section{B Harris Scarfe v Ernst \& Young (No 3) - The Facts}

In Harris Scarfe v Ernst \& Young (No 3) $)^{27}$ ("Harris Scarfe") the action involved claims for damages by various companies in the Harris Scarfe group, which was in liquidation, and by the ANZ Bank which was the major lender to the Harris Scarfe group. The proceedings were brought against three firms of chartered accountants who, at various times, were auditors of companies in the Harris Scarfe group. It was alleged that over relevant periods the defendants had prepared half-yearly reports and reviews negligently, in breach of a contractual duty of care, and in circumstances amounting to misleading and deceptive conduct in breach of s 56 of the Fair Trading Act 1987 (SA).

${ }^{27}$ [2005] SASC 407. 
It was alleged in particular that the defendants had failed to detect that senior management of the Harris Scarfe group had fraudulently manipulated the accounts so as to show substantial operating profits, whereas in reality throughout the relevant period the group has sustained significant losses. The action was being managed in accordance with the provisions of $r 2 \mathrm{~A}$ of the Supreme Court Rules 1987 (SA) as a complex action. The plaintiffs' statement of claim had appeared to be settled and orders had been made requiring the defendants to file amended defences by the middle of November 2005.

It was estimated the trial would occupy at least six months, although it could be substantially more. The plaintiffs were represented by common solicitors and counsel, with the three defendants being represented by two sets of counsel.

The plaintiffs submitted that the case was one in which the use of an electronic court was appropriate and would have numerous advantages. The first defendant supported the use of technology for the trial and the pre-trial preparations. The second and third defendants raised a number of specific objections and issues for the consideration of the court, namely:

- did the court have the power to direct, without agreement, the use of an electronic courtroom?;

- was it too early to make a decision as to the potential utility of an electronic courtroom because the proceedings were not sufficiently advanced?

- to what extent should technology be used?

- what were the costs implications, and who should bear the expense associated with the establishment and use of an electronic court, particularly if required by court order?

\section{Jurisdiction for Orders as to Use of Technology}

The recent practice notes in Victoria, New South Wales and South Australia authorise the court to direct the use of technology at trial ${ }^{28}$. However, even in

\footnotetext{
${ }^{28}$ Practice Note No 1 of 2007, Guidelines for the Use of Technology in any Civil Litigation Matter (Vic) specifically authorises the Court to make a range of orders, including (at 2.8.6) that there be an electronic trial of the proceeding. It also specifies (at 2.9) a range of orders which may be included in the order for the electronic trial of the proceeding. Practice Note No SC Gen 7 Supreme Court - Use of Technology
} 
the absence of a specific authority of this kind in a practice direction or note, there are two potential sources of jurisdiction for the making of such orders: the rules of court, and the inherent jurisdiction of the Court.

\section{$1 \quad$ Rules of Court - Power to Give Directions}

In Harris Scarfe $v$ Ernst \& Young (No 3$)^{29}$ Bleby J was satisfied that the rules of court gave him the specific power to make orders for the use of technology at trial. He referred in particular to 55.11 of the Supreme Court Rules 1987 (SA). That rule is a clear source of jurisdiction for the court to direct the parties to use technology in the litigation process and at trial. It provides that the Court may give such directions as are proper with respect to:

(y) the use of any litigation support system or any other computer process considered appropriate by the court.

Though only a few jurisdictions include a specific power to make directions involving the use of technology ${ }^{30}$ the rules of court in most jurisdictions also

(NSW) specifies as one of the purposes of the Practice Note that it is to "emphasise the court's power to require the use of technology in particular cases or circumstances" (para 4). The current New South Wales Practice Note also states that the court retains the power to direct parties to use information technology in appropriate cases (para 10). There was not such an express power under Practice Note No 105 Use of Technology in Civil Litigation, published in March 1999, which was the relevant Practice Note at the time of the decision in Idoport Pty Ltd $v$ National Australia Bank Limited [6] [2000] NSWCA 338. Practice Direction 2.1 of Supreme Court Practice Directions 2006 (SA) Guidelines for the Use of Electronic Technology, which applies on and after 4 September 2006 and to actions which are governed by the Supreme Court Civil Rules 2006 (SA) now also authorises the making of a range of orders, including (in relation to the use of technology at the hearing) a direction that the parties confer with, or engage, an electronic service provider: see 2.1.23. There was no similar express authority under Direction No 52 Guidelines for the use of technology in litigation in any civil matter (SA), which was issued on 17 August 2001 and was the relevant Practice Direction at the time of the decision in Harris Scarfe v Ernst \& Young (No 3) [2005] SASC 407.

${ }^{29}$ [2005] SASC 407.

${ }^{30}$ Uniform Civil Procedure Rules 2005 (NSW) r 2.3 authorises the court to give directions and make orders relating to "...the use of telephone or video conferencing facilities, videotapes, film projection, computer and other equipment and technology." There is also a specific power in the Rules of Supreme Court 1971 (WA) in relation to interlocutory proceedings: O 29A r3(2) provides that a case 
provide a general power to give directions about the conduct of a matter. ${ }^{31}$ In Queensland, for example, r 367(1) of the Uniform Civil Procedure Rules 1999 (Qld) provides:

(1) The court may make any other order or direction about the conduct of a proceeding it considers appropriate, even though the order or direction may be inconsistent with another provision of these rules.

This rule provides the court with a wide discretion and is sufficiently broad to extend to a direction requiring the adoption of technology in the litigation process. This construction is consistent with the view expressed by Bleby $\mathrm{J}$ in Harris Scarfe. Although his Honour found the specific power in the South Australian Rules of Court to make the orders sought, he also found the power to be conferred by r 3.04, which is the South Australian equivalent to $\mathrm{r} 367(1)$ of the Uniform Civil Procedure Rules 1999 (Qld) and gives the court a general power to give directions about the conduct of a matter. ${ }^{32}$

An argument was made for the second and third defendants in Harris Scarfe to the effect that r 78.01(2) of the Supreme Court Rules 1987 (SA) restricts the Court's ability to make the orders sought. That rule enables the Court to order that evidence of any particular fact shall be given at the trial in such manner as may be specified in the order. It enables, for example, directions to be given that the evidence-in-chief of certain witnesses be given by written statement. Bleby J rejected the argument. He said ${ }^{33}$ :

It does not restrict in any way directions for the use of technology in the production of such statements or other evidence. Rather, it is another example of the wide discretion conferred on the Court to

management direction may give directions as to the use of videotapes, films, computers and other equipment in any interlocutory proceeding.

${ }^{31}$ See Federal Court Rules 1979 O 10 r 1(1); Court Procedure Rules 2006 (ACT) r1401(1); Uniform Civil Procedure Rules 2005 (NSW) r 2.1; Supreme Court Rules 2000 (Tas) rr 415, 425, 550; Uniform Civil Procedure Rules 1999 (Qld) r 367(1); Supreme Court Rules 1987 (SA) r 3.04, Supreme Court Civil Rules 2006 (SA) rr 116, 117; Supreme Court (Miscellaneous Civil Proceedings) Rules 1998 (Vic) rr 2.04, 3.04, 8.05.

${ }^{32}$ Supreme Court Rules 1987 (SA) r3.04 provides that the court has power, in any case in which it thinks it just to do so to ...(g) Do all or any acts or give any directions relating to the conduct of an action subject to such terms as to costs or otherwise as it thinks proper. (See now Supreme Court Civil Rules 2006 (SA) rr 116, 117.)

33 [2005] SASC 407 at [16]. 
direct the giving of evidence in a manner that is efficient and appropriate. [emphasis added]

\section{Rules of Court - Overriding Objective}

In his judgment in Idoport ${ }^{34}$ Einstein $\mathrm{J}$ did not base his judgment on the court's power under the rules of court to make directions. He referred, however, to Supreme Court Rules (Amendment No 337) 2000 (NSW) which inserted a new Part 1 Rule 3 into the Supreme Court Rules 1970 (NSW). The new rule provided in particular:

3(1) The overriding purpose of these rules, in their application to civil proceedings, is to facilitate the just and cheap resolution of the real issues in such proceedings.

(2) The court must seek to give effect to the overriding purpose when it exercises any power given to it by the rules or when interpreting any rule.

(3) A party to civil proceedings is under a duty to assist the court to further the overriding purpose and, to that effect, to participate in the processes of the Court and to comply with directions and orders of the Court. ... $^{35}$

The equivalent rule is now found in s 56 of the Civil Procedure Act 2005 (NSW) which sets out the same purpose as applying to that Act and to the Uniform Civil Procedure Rules 2005 (NSW).

In this context the New South Wales rules adopt the statement of overriding purpose as incorporated into the Woolf Reforms introduced in England by the Civil Procedure Rules. ${ }^{36}$ Those rules were introduced in 1999, and replaced many of the provisions of the old Rules of the Supreme Court and

${ }^{34}$ Idoport Pty Ltd v National Australia Bank Limited [2000] NSWSC 338.

${ }^{35}$ The rule was repealed by in 2005 by amendment no 407, Sch 1 [5].

${ }^{36}$ Rule 1.1 of the Civil Procedure Rules expresses the "overriding objective" to enable the court "to deal with cases justly". The court has an obligation to give effect to the overriding objectives in exercising any power given to it under the rules and when interpreting their implementation. The overriding objective encompasses five principles which are given effect to in Rule 1.1(2)(a) - (e). For Lord Woolf's elucidation of those principles see: Lord Woolf: "The Future of Civil Justice" (1997) 3 The Judicial Review pp 103-107. 
County Court rules. They govern the practice and procedure to be followed in the civil division of the Court of Appeal, the High Court, and county courts.

When delivering his judgment in Idoport ${ }^{37}$ Einstein $\mathrm{J}$ observed that no Australian cases had by that time considered the "overriding purpose" clause $^{38}$. Einstein $\mathrm{J}$ did, however, refer to a number of recent English cases which had considered the operation of the "overrriding objective" as providing a possibly valuable source of persuasive authority, although he noted as a point of distinction that the Woolf reforms included, but were more extensive than, the insertion of an overriding purpose clause. ${ }^{39}$ His Honour also referred to a number of academic writings in relation to the overriding objective clause. ${ }^{40}$ Though all of the cases and writings referred to addressed some aspects of the overriding objective clause none dealt specifically with the interrelationship between the overriding purpose and the role that may be played by technology in the litigation process.

As Sandy has observed, ${ }^{41}$ the existence of the overriding principle provides the court with significant discretionary powers to ameliorate the rigour of the rules of court, but it also makes the judicial process less certain and subjective and one judge's perspective on what constitutes the interests of justice may be radically different from his or her judicial companions. Whether it is in the interests of justice to use technology in the litigation process and at trial is certainly an issue upon which different judges may have different views, depending upon their own expertise and experiences. It is clear that, however, that Einstein $\mathrm{J}$ was of the view that the giving of an

37 Idoport Pty Ltd v National Australia Bank Limited [2000] NSWSC 338 at [19]. This judgment was delivered on 14 April 2000.

38 This observation was arguably inaccurate: certainly the Queensland Court of Appeal had considered the equivalent Queensland rule in Thomas $v$ NAB Ltd [1999] QCA 525, as discussed below.

${ }^{39}$ Shikari v Malik [1000] TLR 391; Christofi v Barclays Bank Plc [1999] TLR 487; Cowland \& Kendrick v Judges of the West London County Court (unreported, Court of Appeal (Civil Division), 20 July 1999; Stephenson (SBJ) Ltd v Mandy [1999] TLR 550; Mullan v Birmingham City Council [1999] TLR 573; MacDonald v Thorn Plc [1999] TLR 691; Biguzzi v Rank Leisure Plc [1999] 1 WLR 1926.

40 Richard Harrison, "Will Woolf Change the Way We Behave?" (1998) 148 New Law Journal at 1853-1854, Lord Browne-Wilkinson, "The UK Access to Justice Report: A Sheep in Woolf's Clothing” (1999) 28 The University of Western Australia Law Review pp183-186, Gordon Exall, "Civil Litigation Brief: Woolf Reforms (3)" (1999) 143 Solicitors Journal, p112; David Sandy, "Dealing Justly" at www.simmons-simmons.com/woolf/dealing.htm.

${ }^{41}$ Sandy, above n 40. 
order requiring the use of technology, including its use at the trial of the proceeding, could be necessary in order to achieve the overriding objective.

In Harris Scarfe ${ }^{42}$ Bleby J noted that the particular rules of the Supreme Court of New South Wales in relation to the overriding purpose of the rules of court, as referred to by Einstein $\mathrm{J}$ in Idoport, have their equivalents in South Australia in $\mathrm{r} 2.01^{43}$, which provides:

These rules are made for the purpose of establishing orderly procedures for the conduct of litigation in the Court and of promoting the just and efficient determination of such litigation. They are not intended to defeat a proper claim or defence of a litigant who is genuinely endeavouring to comply with the procedures of the court, and are to be interpreted and applied with the above purpose in view.

In the light of this rule his Honour was satisfied that the considerations Einstein J referred to in Idoport also applied to actions in the Supreme Court of South Australia, and it is apparent from his judgment also that his Honour was satisfied that it could well be necessary in the interests of justice to order the use of technology at the trial of a proceeding.

The Rules of Court in several other jurisdictions now include an express requirement that the rules of court be construed and applied so as to achieve objectives which include the promotion of justice and efficiency in the litigation process. ${ }^{44}$ The relevant rule in Queensland is $\mathrm{r} 5$ of the Uniform Civil Procedure Rules 1999 (Qld). This rule sets out the "philosophy" of the rules in terms of the overriding obligations of the parties and the court. It states:

5. (1) The purpose of these rules is to facilitate the just and expeditious resolution of the real issues in civil proceedings at a minimum of expense.

(2) Accordingly, these rules are to be applied by the courts with the objective of avoiding undue delay, expense and technicality and facilitating the purpose of these rules.

${ }^{42}$ [2005] SASC 407.

${ }^{43}$ See now Supreme Court Civil Rules 2006 (SA) r 3.

${ }^{44}$ Court Procedure Rules 2006 (ACT) r 21; Uniform Civil Procedure Rules 1999 (Qld) r 5; Rules of Supreme Court 1971 (WA) O 1 r 4(B). 
(3) In a proceeding in a court, a party impliedly undertakes to the court and to the other parties to proceed in an expeditious way.

(4) The court may impose appropriate sanctions if a party does not comply with these rules or an order of the court.

Rule 5-(1) \& (2) were interpreted and applied by Pincus $\mathrm{J}$ in Thomas $v$ NAB $\operatorname{Ltd}^{45}$ :

"The proper interpretation of this rule appears to be that, when faced with an established practice which can lead to 'undue delay, expense and technicality', the Court should attempt to avoid these results." [emphasis added]

It is submitted that if the conduct of a traditional paper-based trial would clearly be far more time-consuming and costly than its conduct in an electronic court it is at the least arguable that the parties would be in breach of their implied undertaking to the court in rule 5(3) to decline to use the electronic court. Further, consistent with the views of Pincus J in Thomas the court should attempt "to avoid the result" which would follow from the adoption of "established practice." One way it may do this is to exercise its power to give directions about to the conduct of a matter ${ }^{46}$ to direct that the trial proceed in an electronic court.

\section{$3 \quad$ Inherent Jurisdiction}

Although satisfied that the rules to which they had referred, particularly when interpreted in the light of the overriding purpose of the rules, were sufficient foundation for the making of the orders proposed, both Einstein $\mathrm{J}$ in Idoport ${ }^{47}$ and Bleby $\mathrm{J}$ in Harris Scarfe ${ }^{48}$ were satisfied that the court also had inherent jurisdiction to make the orders sought.

\footnotetext{
45 [1999] QCA 525 at [35].

${ }^{46}$ Uniform Civil Procedure Rules 1999 (Qld) r 367(1). See also Federal Court Rules 1979 r 10.1(2); Court Procedure Rules 2006 (ACT) r1401; Uniform Civil Procedure Rules 2005 (NSW) r 2.1; Supreme Court Rules 2000 (Tas) rr 415, 425, 550; Supreme Court (Miscellaneous Civil Proceedings) Rules 1998 (Vic) rr 2.04, 3.04, 8.05.

${ }^{47}$ Idoport Pty Ltd v National Australia Bank Limited [2000] NSWSC 338.

${ }^{48}$ Harris Scarfe v Ernst \& Young (No 3) [2005] SASC 407.
} 
In Idoport Einstein $\mathrm{J}$ had referred to a range of decisions on the court's inherent jurisdiction to exercise powers necessary to enable it to act effectively within its jurisdiction ${ }^{49}$ including an untrammelled power of regulating its own proceedings. ${ }^{50} \mathrm{He}$ noted the purpose of the implied jurisdiction was to allow the Court to make such orders as to enable it to uphold, protect and fulfil the judicial function by ensuring that justice is administered according to law and in an effective manner ${ }^{51}$ and that it was proper to exercise the power not only where it was necessary to do so, but also to secure or promote convenience, expedition and efficiency in the administration of justice. ${ }^{52}$ His Honour also referred to the articulation in the rules of the overriding objective of enabling the court to deal with cases justly, as discussed above, and proceeded: ${ }^{53}$

Hence the inherent jurisdiction of the Supreme Court to regulate its own proceedings so as to promote matters relating to convenience, expedition and efficiency in the administration of justice, includes directing or ordering the parties to use certain procedures, if the benefits derived from the use of such procedures justifies the costs and will ensure that the trial proceeds quickly and efficiently. [emphasis added]

In Harris Scarfe ${ }^{54}$ Bleby $\mathrm{J}$ adopted the views of Einstein $\mathrm{J}$ in Idoport $^{55}$ in relation to the inherent jurisdiction. His Honour noted in that context that for South Australia the inherent jurisdiction of the court to make the orders sought was specifically preserved by the Rules of Court. ${ }^{56}$

${ }^{49}$ Connolly v Director of Prosecutions [1964] AC 1244 at 1301 per Lord Devlin.

${ }^{50}$ Abse v Smith [1986] 1 QB 536 at 555 per May LJ.

51 John Fairfax and Sons $v$ Police Tribunal (1986) 5 NSWLR 465 at 476 per McHugh JA.

${ }^{52}$ O’Toole v Scott [1965] AC 939 at 959 per Lord Pearson.

53 [2000] NSWSC 338 at [15].

54 [2005] SASC 407 at [13].

${ }^{55}$ Idoport Pty Ltd v National Australia Bank Limited [2000] NSWSC 338 esp at [10][15].

${ }^{56}$ Supreme Court Rules 1987 (SA) r 3.06 provides: The provisions of these rules are in addition to, and shall not derogate from, any inherent jurisdiction of the court. See now: Supreme Court Civil Rules 2006 (SA) r6(3). The rules of court in Western Australia also expressly reserve the inherent power of the court to control the conduct of a proceeding: Rules of Supreme Court 1979 (WA) O 1 r 3A. 


\section{$4 \quad$ Interests of Justice}

The common theme that emerges from the analysis of any of the potential sources of jurisdiction for the court to order the use of technology in the litigation process or at trial, whether in the exercise of its power under the rules to make directions relating to the conduct of a matter, in reliance upon provisions as to the "overriding purpose" or the "philosophy" of the rules, is that the court must be satisfied that the use of technology will assist to ensure that the action proceeds quickly and efficiently. It will in that event be in the interests of justice to make such orders.

\section{WhEN DO THE INTERESTS OF JUSTICE CALL FOR THE USE OF TECHNOLOGY IN LITIGATION?}

It is interesting to note that in Idoport $^{57}$ the basis for the defendants' resistance to the use of the technology court at trial was not a fundamental opposition to the use of technology in the litigation process. Indeed, in principle the defendants embraced the concept of the use of technology where appropriate to assist the parties and the courts to dispose of the proceedings as quickly as possible. Their submission, however, was that at the end of the day, for various reasons, the use of that court would not be efficient in relation to the proceedings at hand. ${ }^{58}$

For the plaintiffs it was contended that the Technology Court should be used because that would be an efficient manner of seeking to get through the hearing in a practicable way in the minimum of time, consistent with the obvious requirements that all parties should be permitted to take time and care in the presentation of their respective cases. ${ }^{59}$

To come to some conclusions about whether and when the court may determine that the interests of justice will be furthered by the use of technology either in the litigation process or at trial, it is necessary to examine the advantages that the use of technology may offer over conventional procedures for both trial preparation and trial, with a view to clarifying the circumstances in which it may be found that "the benefits

\footnotetext{
${ }^{57}$ Idoport Pty Ltd v National Australia Bank Limited [2000] NSWSC 338.

${ }^{58}$ Idoport Pty Ltd v National Australia Bank Limited [2000] NSWSC 338 at [5].

${ }^{59}$ Idoport Pty Ltd v National Australia Bank Limited [2000] NSWSC 338 at [6].
} 
derived from the use of such procedures justifies the costs and will ensure that the trial proceeds quickly and efficiently."

\section{A Pre-Trial \\ $1 \quad$ Document Management Systems - Key Features}

While the conduct of an electronic trial may be the desirable outcome for large scale litigation, the first step in the process, namely the adoption of a quality document management system, of itself provides a range of benefits. ${ }^{61}$

It is possible to have a suitable database custom-built. As time has gone by an increasing number of larger law firms developed their own in-house software to manage litigation documents, usually through a customised Microsoft Access database.

There are also now several commercial providers in Australia providing a range of quality litigation support systems. ${ }^{62}$ For law firms which do not want to invest in information technology capital, particularly if the technology might only be required for a single case, there is now also an option of renting access to the required technology. The requisite software is available in an environment independent of the firm's own network and can be securely accessed across the internet.

Entrepreneurs have also seen the potential for businesses which could provide document management expertise to law firms in a cost-effective way to provide it commercially and now many litigation practitioners, most often the small and medium firms, outsource their document processing to a litigation support bureau.

${ }^{60}$ Idoport Pty Ltd v National Australia Bank Limited [2000] NSWSC 338 at [15].

${ }^{61}$ See: S Drummond, "The limits of discovery", Lawyers Weekly, 27 May 2005. For discussion of the advances in technology for disclosure and litigation support in the US, see Robert Hart, "Getting over the paper chase" (2000) 22(4) Ohio Lawyers Weekly.

${ }^{62}$ For discussion of the various features of leading litigation support products on the Australian market see Deborah Coram and Adam Seskis, "Litigation Support Systems", Lawyers Weekly, 31 May 2002 14. See also Sandra Potter and Peter Moon, "Guidelines for the use of technology in civil matters" (1999) 73(9) Law Institute Journal 62 at 63-64 for discussion of the then available technologies and their respective advantages and disadvantages. 
To obtain the benefits available through the adoption of technology pre-trial the documents need to be put into the database. Databases have two essential parts: the documents themselves, and the descriptive information about the documents, attached to the documents.

If the documents have not been produced electronically, or if they are documents such as letters, plans, invoices etc, that have been produced by others and are not available to a party in electronic form, then they must be scanned and an electronic copy stored.

Once an electronic copy of the documents has been stored, information about that document needs to be put into the database. The various practice directions that have been outlined assist in suggesting the appropriate information to include. Some of it is quite obvious and is the sort of information that has always been included in the list of documents for discovery or disclosure, such as the date and the author of the document.

Though not essential for documents stored only in a paper environment, an essential piece of information for each document to be included in an electronic database is the document identification number. Each page of each document must be identified with a unique barcode. This only needs to be done once, before the documents are processed. This document identification must be done in a logical and consistent way. Accuracy in allocation and entry of this information is extremely important because this is the means by which the database is effectively able to identify any particular document amongst the hundreds or thousands of documents. If incorrect information is put into the database then it is unlikely to work accurately.

An increasing proportion of all documents are produced electronically. ${ }^{63}$ Although it is usually quite a simple process to add these to the database the completion of the descriptive information about the documents can at present be time-consuming and costly. Although emails will necessarily capture the necessary meta data there are many electronic documents, including email attachments, for which the necessary meta data is either not captured, or not captured in a meaningful way. Work is being undertaken towards the

${ }^{63}$ See S Potter and P Farrelly, "Managing e-files in discovery in civil litigation matters" (2003) 77(7) Law Institute Journal 38. The authors refer to research by the Gartner Group which shows that $80 \%$ of data created in the last 20 years exists in electronic form, and that $97.3 \%$ of all documents created in 2003 were electronic. The article also discusses some of the practical issues that may arise in relation to discovery of electronic data. 
development of standards for legal documents and applications and this will assist to address the issues and reduce the costs currently involved in dealing with documents produced in electronic form. ${ }^{64}$

\section{Document Management Systems - the Benefits}

Once the documents and the requisite information about them are in a database a number of facilities are available that are not on offer in a paperbased environment.

\section{- Processing}

It is only necessary to scan documents once, and they can then be used in a number of contexts, such as for exchanging of electronic copies of documents with other parties, preparing electronic court books and preparing electronic appeal books. The database can store not only material disclosed by a party or obtained through disclosure, but also other documents such as file notes, counsel advices etc.

- Sort, search, locate

Documents can be grouped in any desired way and located quickly. Lawyers are able to assign documents to particular issues in a case. As an example, a party may wish to view all of the documents relevant to a particular issue, or all of the documents dated between particular dates, and these documents can be immediately identified and quickly located. With paper documents it would take someone considerable time to locate and retrieve these documents, even if they had been indexed in electronic form.

In a similar way it may be that in the course of trial preparation, or during trial, a specific document assumes some particular importance. The database can be searched to find quickly any other documents in which the document of interest was mentioned.

\footnotetext{
${ }^{64}$ For more detailed consideration of the issues involved in the discovery of documents produced in electronic form and suggestions as to how these issues are likely to be addressed in the future, see A. Stanfield, E-Litigation, Thompson Legal and Regulatory Group, 2003 at 55-56.
} 
- Space-saving, portable

Digital storing of documents greatly reduces physical storage space required. There is no need to rely on hard copies of any document and therefore no need to carry folders of documents between offices or to court. Hard copies of documents can be reproduced at any time, if required.

\section{- Collaboration, notation}

The client, solicitor and counsel can all be in different locations but go on-line and access the documents from anywhere. Notes may be made by one person on a particular document and these can be viewed by the other members of the litigation team when they open the document. This enables collaboration even though those involved are at different physical locations and are accessing the documents at different times.

- Electronic trial

The adoption of a quality electronic document management system at the pre-trial stage facilitates the use of technology at the trial in the proceeding. The benefits technology may then bring to the trial are discussed further below.

The use of an electronic document management system enables litigation practitioners to access all of their client's documents at the touch of a keystroke from their computers, or from any other computer connected to the internet. Disclosure can be undertaken by simply handing over a CD-Rom instead of mounds of hard copy documents.

It is obvious, however, that the benefits are greater the more documents are involved as it means thousands of documents can be accessed, searched, sorted, etc as simply as hundreds.

\section{B Trial}

As has been mentioned, there is no clear definition of an "electronic court." Although the conduct of a trial electronically may include the use of a wide range of possible features, the following is a useful list of basic features 
suggested by Stanfield as necessary for the effective working of an ecourtroom $^{65}$ :

- Collection of documents in a consistent electronic format

- Adequate preparation using the electronic tools

- The courtroom itself

- Hardware

- Electronic court Book

- Transcription management

- Visual display system

- Court operator

- Appropriate expertise to support the system

- Adequate training and preparation for using the electronic tools

It may also be noted that the New South Wales Practice Notice refers to some of the commonly used equipment and services that parties may seek to have available in the courtroom or jury deliberation room during the hearing, including real time transcript, video-conferencing, and computers at the bar table. ${ }^{66}$

The benefits which may be brought to a trial through the use of technology were discussed by both Bleby J in Harris Scarfe ${ }^{67}$ and Einstein J in Idoport ${ }^{68}$. They include the ability for parties to conduct a trial to a large extent in a "paperless" manner. Relevant documents on the court file, such as pleadings, particulars, document lists and affidavits are stored and can be retrieved as required. Other documents such as witness statements, expert reports, chronologies, lists of documents and outlines of argument can also be presented electronically. The database also incorporates documents which will be, or are likely to be, tendered at the trial. The electronic version of the transcript will also be included and there is an option to incorporate real time transcript of the proceedings. If that option is taken it is also possible at the end of each day to email transcript to media outlets that may have requested it.

Secure and efficient access to all of the documents described is available to the trial judge, the court staff and the parties, and in the courtroom and

${ }^{65}$ A. Stanfield, E-Litigation, Thompson Legal and Regulatory Group, 2003 at 71.

${ }^{66}$ Practice Note SC Gen 7 Supreme Court - Use of Technology, published 15.8.06.

${ }^{67}$ Harris Scarfe v Ernst \& Young (No 3) [2005] SASC 407 at [17] -[22].

${ }^{68}$ Idoport Pty Ltd $v$ National Australia Bank Limited [2000] NSWSC 338 at [42][78]. See also the description of the "electronic" courtroom used in Seven Network Limited $v$ News Limited (No 9) [2005] FCA 1394 at [4]-[5]. 
elsewhere. This means that people involved in the trial are able to work more efficiently given that materials will be available remotely after hours, and the movement and physical accommodation of the materials will not be necessary. If the necessary computers are available in court for the duration of the trial it also means there is no need for parties to carry equipment such as lap top computers to court, or for judges to move such equipment between chambers and the court room.

During the trial documents, and if necessary more than one document at a time, may displayed to persons in the courtroom on monitors with plasma screens set up for this purpose. In the courtroom itself, counsel, solicitors, the witness, the judge and the judge's associate each have such facilities available. There is also the facility for users to "freeze" a document they wish to keep in front of them, and to move between related documents and transcript by way of hyperlinks.

Exhibits and documents for identification can be marked appropriately, with exhibit markings including information about the basis of tender, any qualifications on tender and admission, and transcript references at the point of tender. Subsequent references by witnesses and counsel to the exhibit can also be incorporated.

Users have the ability to create documents, or to annotate documents and transcript, for private use and access or for access by a restricted group, such as counsel and solicitors for one party only. Documents which would ordinarily be publicly available on a hard copy court file, including evidentiary material once it is before the court ${ }^{69}$, can be separated out from the other documents to which access must be restricted. Masking of parts of documents can be easily accommodated. This means there is no difficulty in protecting confidentiality of commercially sensitive documents or parts of documents.

Other available features include contact information, calendar and messaging capabilities and an interface with the internet providing immediate access to most relevant case law and legislation.

The ability to sort and index documents, which provides enormous benefits pre-trial, is also useful during the course of the trial, as are the powerful search facilities that enable quick and easy reference to documents and

${ }^{69}$ In Seven Network Ltd $v$ News Ltd (No 9) [2005] FCA 1394 the Federal Court referred to such documents as a "media courtbook". 
relevant transcript across the system. The quick access to documents in court promotes efficient use of court time. The ability to search, in particular, saves many hours of work from the point of view of counsel, the judge and the judge's staff.

Certainly the use of a quality document management system means that counsel can access any document he or she wants quickly and efficiently. There is no need to hunt through folders of hard copy documents, or to try to remember which folder particular documents are in, or in larger litigation, which trolley they are on. Exhibits and real time transcript can be added to the database during trial and can be noted and cross-referenced as required.

For optimal use of the features of an electronic court the systems which the parties have adopted at the pre-trial stage need to be made compatible with the system set up for the electronic trial.

A range of other features may be included in a set up for an electronic trial ${ }^{70}$. The system used for the enquiry into the Glenbrook Railway disaster allowed the addition of audio evidence (involving recordings from signal operators and train drivers) in digital formal, accessible through the database. ${ }^{71}$ Another well-publicised trial that proceeded in an electronic court was the Bell Group case: the longest running civil trial in the history of Western Australia and Australia's biggest corporate recovery claim $^{72}$. The trial in that case, for example, also made extensive use of video-conferencing facilities which were used to bring witnesses into the courtroom from anywhere in the world as though they were addressing the court ${ }^{73}$.

${ }^{70}$ For discussion of a range of innovative uses of technology in litigation see the Victorian Law Reform Committee, Technology and the Law 1999, Final Report, at http://www.parliament.vic.gov.au/lawreform/tech/, esp at ch 10. This chapter also includes detailed explanation of the features of the special courtroom set up for the Estate Mortgage Litigation (See 10.11-10.16).

${ }^{71}$ Jeff Leeuwenberg and Anne Wallace, Technology for Justice 2000, AIJA (2001), 9 .

${ }^{72}$ The case involved a $\$ 1.4$ billion recovery claim by the former Western Australia Government Insurance Commission against a consortium of 20 banks used by the former Alan Bond company, the Bell Group Limited.

${ }^{73}$ See: S Tarling, "E-trial ushers in judgment day for IT", The Age, 23.9.2003 at: http://www.theage.com.au/articles/2003/09/22/1064082/2340.html, accessed 25.1.06. This article includes an outline of the features available in the court established for that trial. See also J Leeuwenberg and A Wallace, Technology for Justice 2002 Report, The Australian Institute of Judicial Administration Inc, at: http://www.aija.org.au/tech3/.report.pdf, accessed 3.1.06, at 4. The authors there note 
Following his consideration of the features possibly available at trial through the use of technology Bleby $\mathrm{J}$ in Harris Scarfe ${ }^{74}$ concluded that the advantages of an electronic court were "numerous and manifestly obvious." Significantly, however, he qualified this by reference to "a long and complex matter such as the one at hand".

In a case such as the one before him Bleby $\mathrm{J}$ thought the reduction in trial time would be likely to be substantial. His Honour indicated that a conservative estimate as to the length of trial in the matter before him was six months, and that it could well take longer. He noted in that regard that it would be necessary to call many witnesses, and that a large number of documents would be tendered. The collective costs of each day that the trial continued, including costs of senior counsel and at least one firm of principal instructing solicitors from interstate, would be substantial. Accordingly, in his Honour's view, even a minor reduction in the length of trial would deliver substantial cost savings.

\section{Threshold Number of Documents?}

The cases that have been conducted in an electronic court have in most instances been highly publicised and long-running trials, such as the Bell Group case, the Estate Mortgage case and the Longford Royal Commission in Victoria, the trial in Queensland in Emanuel Management Pty Ltd (in liq) $v$ Foster's Brewing Group ${ }^{75}$, and the recent proceeding in the Federal Court brought by Seven Network Limited, alleging breaches of the provisions of the Trade Practices Act 1974 (Cth) in the bidding for television rights to Australian Football League and National Rugby League games. ${ }^{76}$

A time and cost comparison of tasks that need to be performed in a manual environment compared with those performed in an automated environment will undoubtedly indicate a saving when large volumes of documents are involved. A sample provided by Deborah Coram and Adam Seskis in their

that one of the issues the courts will have to grapple with is the way in which the delivery of justice can or should take place in "virtual reality" as opposed to the physical environment of a courtroom.

${ }_{74}^{74}$ Harris Scarfe v Ernst \& Young (No 3) [2005] SASC 407 at [19].

${ }^{75}$ [2003] QSC 299.

${ }^{76}$ Seven Network Limited $v$ News Limited [2007] FCA 1062. For an outline of the dimensions of the hearing of this litigation see "1.2 The Hearing" at [6]-[9]. 
article "Litigation Support Systems" expended in managing a matter with a litigation support system almost halves the cost and time spent without the use of such a system. But this study is based on 20 folders of documents comprising 7000 pages and 2,300 documents.

In a similar vein, and although clearly supporting the adoption of technology in the case at hand as delivering a range of benefits, the judgment of Bleby $\mathrm{J}$ in Harris Scarfe ${ }^{78}$ makes it clear that this was because the matter was "long and complex". There is undoubtedly significant expense involved in establishing and running an electronic court. The wiring of the court used for the trial in the Bell Group case, for example, was estimated at some $\$ 860,000^{79}$ and this expense would not be justified in the simplest of litigation matters involving only a very small number documents.

Developments in hardware over recent years, however, have meant that the use of technology may be cost-effective in a wider range of cases ${ }^{80}$, and also mean that parties and the courts may be able to use only that part of the available technology that suits the particular case, rather than necessarily adopting a whole system. In Harris Scarfe ${ }^{81}$ Bleby J acknowledged the significant expenses involved in establishing an electronic court, but found them to be insignificant when viewed against the costs which would necessarily be incurred in taking the matter before him to trial and also against the amount of damages being sought. His Honour commented, however ${ }^{82}$ :

Much shorter trials than the one presently contemplated have been seen in other jurisdictions to warrant the use of this type of courtroom technology in the interests of efficiency.

\footnotetext{
${ }^{77}$ Above n 62, 15.

${ }^{78}$ Harris Scarfe v Ernst \& Young (No 3) [2005] SASC 407 at [19].

${ }^{79}$ Tarling, above $\mathrm{n} 73$.
}

${ }^{80}$ Jeff Leeuwenberg and Anne Wallace, Technology for Justice 2000, AIJA (2001), 10. The authors refer in particular to the development of large format flat screen monitors that are better suited for courtroom use; improvements in the size, reliability, capacity and price or personal computers. They note it is relatively easy to put together a basic courtroom display kit, suitable for semi-portable use and quick to set up, using a laptop, 4-5 screens, CD-ROM burner, a document camera, scanners and basic cabling.

${ }^{81}$ Harris Scarfe v Ernst \& Young (No 3) [2005] SASC 407.

${ }^{82}$ Harris Scarfe v Ernst \& Young (No 3) [2005] SASC 407 at [22]. 
Unfortunately, this comment was not supported by reference to particular cases, nor does it explain further the circumstances in which it will be efficient for "much shorter trials" to be conducted in an electronic court. However in this case, as in the other cases that have been discussed, little is said to provide guidance as to the point at which the benefits of the adoption of technology will outweigh the costs.

Examples certainly can be found of shorter trials that have been conducted electronically. One example is the challenge by Visa International and Mastercard to the Reserve Bank's decision to bring the credit card schemes under its regulatory control. ${ }^{83}$ In providing a summary of the principle issues and some of his principle reasons for judgment in the matter (before publishing his full reasons for judgment) Tamberlin J said:

Due to the use of advanced courtroom technology...the hearing was reduced to the relatively short period of six weeks. Without this assistance from the technology and cooperation of the litigants, the hearing could have extended over many months.

In most of the jurisdictions that have adopted a practice note or direction about the use of technology, as discussed above, a threshold number of documents likely to be discoverable has been stipulated as triggering the court's expectation that parties consider the use of technology to exchange document data. There was initially some considerable variation in the number of documents specified, but the number now specified in each of New South Wales, the Northern Territory, South Australia and the Federal Court is 500. ${ }^{84}$

${ }^{83}$ Visa International Service Association v Reserve Bank of Australia [2003] FCA 977.

${ }^{84}$ New South Wales: Practice Note SC Gen 7 Supreme Court - Use of Technology, published 15 August 2006 with effect from 1 September 2006; NT: Practice Direction No 2 of 2002, Guidelines for the use of Technology in any Civil Matter, published 13.2.2002; SA: Practice Direction 2.1 of Supreme Court Practice Directions 2006 (SA) Guidelines for the Use of Electronic Technology, with effect from 4.9.2006 in relation to actions governed by Supreme Court Civil Rules 2006. This Practice Direction refers to the number of documents likely to be disclosed is more than 500, or when the estimated length of hearing is more than four weeks. (The previous Practice Direction (Supreme Court Practice Direction 52) continues to apply to actions governed by the Rules of Supreme Court 1987. It requires parties to consider exchanging details in an agreed electronic format using agreed fields and to consider the use of document images if they believe they will be discovering more than 200 documents between them.); Federal Court: Practice Note 17 Guidelines for the Use of Technology in Litigation in any Civil Matter, published April 2000. 
This is also the number specified in Queensland as a trigger for parties' consideration of the use of technology at trial. ${ }^{85}$ The threshold number of documents under the previous Victorian Practice Direction was $500^{86}$, but the new Practice Direction in that jurisdiction requires consideration of the use of technology "where it might lead to the more efficient conduct of litigation."

There is no doubt that there is among many in the profession a view that electronic document management and disclosure is a last resort, to be embarked upon only when the volume of documents to be dealt with is such that it cannot possibly be managed by a manual method. Certainly there will need to be a significant culture shift before the profession generally embraces technology for matters involving only the sorts of numbers referred to in the practice notes.

There is, however, a contrasting and perhaps "modern" school of thought that today firms should elect to use litigation support systems as a standard means of litigation management. That has become the norm in many large litigation practices, where internal document management systems are used as a matter of course. Certainly this thinking is urged on the profession as general best practice by those involved in the litigation support services industry, ${ }^{88}$ as you would expect!

When documents are first to be converted from hard copy documents to an electronic format the truth probably lies somewhere between these two extremes and perhaps the most that can be definitively stated to date is that the larger the matter the more likely that the use of technology both pre-trial and at trial will be the most efficient method of conducting the proceeding.

It is clear, however, that as procedures are developed for the discovery and processing of documents in their native electronic format and this becomes common place, the use of litigation support systems will increasingly become the standard practice for litigation management.

\footnotetext{
${ }^{85}$ Practice Direction No 8 of 2004, issued 13.7.2004.

${ }^{86}$ Practice Note, No 1 of 2002 Guidelines for the use of Technology in any Civil Matter, published 29.4.2002.

${ }^{87}$ Practice Note No 1 of 2007, Guidelines for the Use of Technology in any Civil Litigation Matter, issued 8.2.2007.

${ }^{88}$ See eg Deborah Coram and Adam Seskis, above n 62, 15.
} 


\section{TIMING OF DIRECTION}

A question which must be determined in the context of the adoption of technology in the litigation process is the time when the court or the parties should consider that technology be adopted, either pre-trial or at trial.

If a trial is to be conducted electronically it is clearly preferable that the decision in that regard be made as soon as possible. One of the obvious reasons for this to give adequate time for the preparations for conduct of the electronic trial. It will be necessary to discuss the parties' requirements with a service provider and to customise software. It will also be necessary to arrange the provision of hardware. The individuals who will be involved in the trial process will need time to become familiar with the use of the system chosen and to undergo appropriate training. Depending upon whether a technician is to be employed and available in court throughout the trial it may be necessary to train court staff in the operation of the system. If the decision to conduct the trial electronically is not taken at an early stage there is a strong potential that the undertaking of these necessary pre-trial preparations may cause delay.

Another key advantage of an early decision in relation to the conduct of the trial is that it is then more likely that efficient use may be made of technology in the pre-trial process. Byrne J observed in Kennedy Taylor (Vic) Pty Ltd $v$ Grocon Pty Ltd (“Kennedy Taylor")

Experience shows that the later the decision to conduct the trial in electronic form is taken, the consequent savings of time and cost at trial and in preparation for the trial are less.

If the decision to use technology is taken at an early stage the parties will clearly adopt technology in the pre-trial stages. When an electronic database is used in this way it is a quick and simple process to transfer data to the courtbook. A range of other benefits that follow from the adoption of a quality document management system have already been discussed.

If the decision is taken at a later stage and document management systems are not used for all documents to be discovered or disclosed, it may be appropriate for the court to require that only a more restricted range of documents be scanned and coded and uploaded to an electronic database. In

${ }^{89}$ [2002] VSC 32 at [17]. 
Kennedy Taylor ${ }^{90}$ Byrne $\mathrm{J}$ was called upon to determine the scope and content of the databases to be used in conjunction with the electronic courtbook. Orders had been made for the preparation of an electronic courtbook and the plaintiffs applied to expand the scope of the documents to be included. The defendant opposed the application. Byrne J described the test as to which documents should be included in a database being established for use at trial in these terms: ${ }^{91}$

To my mind, a preferable test is "documents which are reasonably expected to be tendered or used at trial". This formulation acknowledges the reality that a relevant document might be put to a witness or otherwise used at trial without its being tendered. In such an event, there is likely to be a saving of trial time and costs, and a minimisation of inconvenience for all parties and the witness, as well as for the Court, if all of these are working from a common paginated bundle of documents.

His Honour declined to make the order sought. Though clearly satisfied he had the power to do so his Honour was not persuaded that the benefits to be derived from ordering the inclusion of additional documents as sought by the plaintiffs would outweigh the costs. He found the plaintiffs had not shown that the proposed extension of the database would "have the consequence that the trial of this proceeding will be more completely, promptly, and economically determined". ${ }^{92}$

The issue as to the appropriate timing for a direction that a trial proceed electronically was also considered by Bleby J in Harris Scarfe. ${ }^{93}$ In that case it was argued for the second and third defendants that the proceedings were not sufficiently advanced for an informed decision to be made as to the use of an electronic court and that the decision should be delayed until at least the finalisation of pleadings and expert reports and ideally until notices to admit and tender lists had been prepared.

Bleby $\mathrm{J}$ referred to the decision of Byrne $\mathrm{J}$ in Kennedy Taylor (Vic) Pty Ltd $v$ Grocon Pty Ltd, ${ }^{94}$ as discussed above. He disagreed that it was too early to decide whether an electronic court would be of assistance. He found there

${ }^{90}$ [2002] VSC 32 at [17].

91 [2002] VSC 32 at [15].

92 [2002] VSC 32 at [23].

${ }^{93}$ Harris Scarfe v Ernst \& Young (No 3) [2005] SASC 407 at [27]-[36].

${ }^{94}$ [2002] VSC 32. 
were numerous aspects of the matter which pointed to the conclusion that, whatever changes might be made to the pleadings and expert reports, the use of an electronic court for the trial was appropriate.

His Honour was also of the view that it could only assist in the preparation of notices to admit, tender lists and the timely preparation of a court book to have the arrangements in place at an early stage. He conceded that the exact course of the trial could not be predicted and that the tendering of some documents would necessarily depend on forensic decisions made by counsel at a later stage, so that it was possible that some documents which would have to be included may never be used. He noted, however, that the decisions as to what should be included in the courtbook and when would depend not only on progressive clarification of issues but on advice as to timing and technical matters by the service provider and co-operation of the parties. In the event of dispute as to the content or timing it would of course be possible to make further recourse to directions of the Court.

The second and third defendants in Harris Scarfe $e^{95}$ also raised the issue that some documents may need to be provided in hard copy form in order to view and comprehend the document clearly. Although conceding it was inevitable that some original documents would need to be produced during the course of the trial, Bleby $\mathrm{J}$ found this to be insufficient to outweigh all of the benefits of an electronic court. His Honour did not consider it likely that such a large number of documents would fall into this category so as to render the use of electronic images pointless. He proceeded ${ }^{96}$ :

The orders I propose to make will not require the uploading of every single discovered document. Furthermore, a substantial number of the documents to be entered will not require scanning because they are already in and were produced in electronic form. Therefore I do not foresee the imposition of huge expense in establishing the database.

Consistent with both authority and the practice directions which have been discussed, it is clear that parties should direct their minds very early in the litigation process to the question whether technology should be adopted. It is submitted the crucial point is that at which it has become apparent that the benefits to be derived from the use of technology, whether in terms of costs and efficiency, or having regard also to other considerations relating to the

${ }_{95}^{95}$ Harris Scarfe v Ernst \& Young (No 3) [2005] SASC 407 at [35].

${ }^{96}$ [2005] SASC 407 at [36]. 
administration of justice which may result from the use of technology pretrial or at trial, justifies the costs associated with the adoption of the technology. At that point the parties should proceed electronically, and if necessary the court may be expected to make the appropriate orders.

\section{EXPENSE}

If parties agree that the proceedings between them should be conducted in an electronic court it is obviously preferable that they reach agreement on issues relating to the associated costs, including what costs should be encompassed, how the costs should be assessed and which party should bear them. In the absence of agreement a number of issues in relation to the costs may arise. The court had to consider a number of such questions in both Kennedy Taylor $^{97}$ and Harris Scarfe ${ }^{98}$.

One key question is how the expense associated with the establishment and use of an electronic court should be borne, particularly if the court orders on an opposed application that the trial in the proceeding be conducted electronically. It is submitted, however, that there are no unique features involved with the use of an electronic court which warrant a departure from normal rules about costs and that those rules are well able to provide adequate compensation in relation to costs once a matter has been determined. $^{99}$

The issue was considered in some detail in Harris Scarfe $e^{100}$, where one of the issues raised by the second and third defendants was that they should not be forced to incur the expense associated with the use of an electronic court against their will. The submission was, however, rightly rejected. As Bleby J observed, ${ }^{101}$ the defendants' costs in relation to the use of technology, at least initially, were no different from any other costs necessarily and properly incurred in the defence of the claim against them. His Honour considered that in South Australia, as in other jurisdictions, costs payable to the technology

${ }^{97}$ Kennedy Taylor (Vic) Pty Ltd v Grocon Pty Ltd [2002] VSC 32.

${ }^{98}$ Harris Scarfe v Ernst \& Young (No 3) [2005] SASC 407.

99 Although the issue of liability for costs is arguably encompassed appropriately by the Rules of Court, a related issue is the extent to which traditional scales of costs, and approaches to the interpretation of these scales, provides adequate recompense for the party who is entitled to recover costs associated with the use of technology.

${ }^{100}$ Harris Scarfe v Ernst \& Young (No 3) [2005] SASC 407.

${ }^{101}$ [2005] SASC 407 at [39]. 
service provider will fall into the category described in Rule 101.07(6)(a) as those "necessarily and reasonably incurred by [a] party in the conduct of the litigation". ${ }^{102}$ He found no reason to distinguish the manner in which costs of using an electronic court should be treated from any other disbursement and that those costs could be dealt with in the usual fashion when it came to taxation of a party's costs.

The usual presumption in most jurisdictions as to the ultimate liability for costs is that costs should follow the event. ${ }^{103}$ Ordinarily the use of an electronic court would not of itself warrant a departure from this presumption. As Bleby $\mathrm{J}$ concluded in Harris Scarfe, if there were circumstances in which costs, including those associated with the use of technology, were to be thrown away, as for example by one party abandoning a particular aspect of their case, then any application in that respect would be decided and assessed on ordinary principles.

In Harris Scarfe ${ }^{104}$ the second and third defendants also submitted that the plaintiffs should bear, at least initially, the entire cost of the use of the electronic court in case it turned out that the technology did not assist in the expeditious conduct of the litigation. Bleby $\mathrm{J}$ did not find it necessary to consider this submission at that stage of the proceedings. Consistent with his Honour's earlier discussion in relation to the benefits of technology he did indicate, however, that he considered it unlikely that the electronic court would prove to be an entirely wasteful exercise. ${ }^{105}$ It is certainly difficult to

102 Supreme Court Rules 1987 (SA) r 101.07 (6)(a). (See now Supreme Court Civil Rules 2006 (SA), r264(2), which specifies that "as a general rule, however, costs are awarded as between party and party (that is, on the basis that the party entitled to the costs will be reimbursed for costs reasonably incurred by the party in the conduct of the litigation to an extent determined by reference to the scale of costs in force, under these rules or the previous rules, when the costs were incurred)"). The following rules are in similar terms: Court Procedure Rules 2006 (ACT) r 1751; Uniform Civil Procedure Rules 1999 (Qld) r 703; Supreme Court Rules 2000 (Tas) r 859; Supreme Court (Miscellaneous Civil Proceedings) Rules 1998 (Vic) r 63.29; Federal Court Rules O 62 r 19. See also the definition in Legal Profession Act 2004 (NSW) s 364, incorporated into the definition of "ordinary basis" of assessment by Uniform Civil Procedure Act 2005 (NSW) s 3.

${ }^{103}$ Supreme Court Rules 1987 (SA) r 101.02(1); Supreme Court Civil Rules 2006 (SA) r263(1). See also Uniform Civil Procedure Rules 2005 (NSW) r 42.1; Uniform Civil Procedure Rules 1999 (Qld) r 689(1); Supreme Court (General Civil Procedure) Rules 2005 (Vic); Rules of Supreme Court 1971 (WA) O 66 r 1.

${ }^{104}$ [2005] SASC 407 at [39].

105 [2005] SASC 407 at [38]. 
envisage circumstances in which there would not be some costs savings resulting from the conduct of a trial with the use of technology, although it has been seen that there has been no research to date as to the precise circumstances in which the conduct of a trial electronically is ultimately more efficient and cost-effective than traditional means. It is submitted that if a party who is liable to pay costs is to benefit from whatever costs savings are made through the use of technology, it is logical and appropriate that the party also bear the costs associated with the use of technology, whether the use of the technology is by agreement between the parties or on the order of the court.

If it is accepted that it is to be expected that in the ordinary course the costs associated with the use of technology will be part of the party and party costs recoverable by the successful party the question becomes what costs will be encompassed. The decision in Kennedy Taylor (Vic) Pty Ltd v Grocon Pty $L t d^{106}$ throws some light on that question. The trial in that matter was to proceed electronically and directions had been given requiring the preparation of an electronic data base of documents for the trial. It had been agreed between the parties that the costs would include ${ }^{107}$ the acquisition of software (including necessary licences), fees payable to external information technology consultants, the scanning of documents, and the coding of documents in accordance with an agreed protocol.

The particular application before the court was one brought by the plaintiffs. They sought an order that all reasonable costs associated with the application of information technology to the preparation for trial, and the trial itself, should be regarded as necessary or proper costs for the purpose of taxation of $\operatorname{costs}^{108}$. The defendant and third party proposed a more restricted order that would extend only to the costs associated with the application of technology to preparation of the court book or otherwise with any order of the court. On the hearing of the application it became clear that the point of difference between the parties related to the ambit of the database of documents. The plaintiff sought to have all, or nearly all, discovered documents included, whereas the other parties desired a much more restricted database resembling

${ }^{106}$ [2002] VSC 32.

${ }^{107}$ Kennedy Taylor v Grocon Pty Ltd [2002] VSC 32 (see esp at [11]).

${ }^{108}$ Supreme Court (Miscellaneous Civil Proceedings) Rules 1998 (Vic) rule 63. Rule 63.29 provides that "On a taxation on a party and party basis all costs necessary or proper for the attainment of justice or for enforcing or defending the rights of the party whose costs are being taxed shall be allowed." 
a traditional court book in electronic form or comprising at most "only those documents with a reasonable prospect of being tendered." 109

The judge considered the usual practice in relation to the preparation of court books and noted that in the ordinary course they should contain "documents which are reasonably expected to be tendered at the trial ${ }^{110}$. In his Honour's view the position was the same if the trial was an electronic one, using imaged documents. He noted, however, that the facility with which documents may be imaged and managed electronically did, however, bear on the principle. This may mean that in a given case an electronic library containing all, or nearly all, the discovered documents, would be no more expensive, or even cheaper, than an electronic courtbook. This would depend upon whether all discovered documents had been imaged, as if they had there would in all likelihood be little further costs involved in transferring the images of all, rather than a selection of them, to the database for use at trial. Indeed, as his Honour pointed out, there may be a saving in the long term, as the task of selection will involve professional time and expense.

In considering issues in relation to expense it should finally be noted that in addition to the issues that relate to the adoption of technology pre-trial and at trial costs issues also arise in relation to the discovery of documents that exist only in electronic form. Discoverable information may be held in a relatively accessible storage medium, such as on a server's hard disk. However back-up tapes, which are often held off-site and require additional user intervention to restore, are by their nature much more difficult to access. ${ }^{111}$ Difficulties will also arise in accessing electronic data which has been erased or damaged. The process of retrieving electronic information of this kind, sifting through it to locate content that should be discovered, and converting it into a suitable format for provision to the other parties, can be an extremely burdensome and expensive process. The usual position will be that the associated costs will be part of the party and party costs ultimately recoverable by the successful party, but in some instances it may be appropriate to ask the court to order that at least part of the costs be paid up front by the party to whom discovery is to be made. ${ }^{112}$

${ }^{109}$ [2002] VSC 32 at [8].

110 [2002] VSC 32 at [15].

111 The costs associated with the restoration of backup tapes was considered in $B T$ Australasia Pty Ltd v State of New South Wales [1998] FCA 363 and in Sony Music Entertainment (Australia) Limited v University of Tasmania [2003] FCA 532.

${ }^{112}$ See Farrell B, "So much for Cheap Technology" (2003) 53 Computers \& Law 13. The author there argues that Australia should look to the model developed in the 


\section{OPEN JUSTICE IN AN E-TRIAL?}

It is the position at general law that judgments and orders of the court are public documents which the public have a general right to inspect. Pleadings, affidavits and other documents merely filed in court are not open to public inspection. ${ }^{113}$ In each jurisdiction the rules of court govern the extent to which the public may access documents in a proceeding. These rules reflect an aspect of the inherent jurisdiction of the court to control and superintend its own proceedings so as to protect and further the due administration of justice. $^{114}$

In some jurisdictions the rules of court expand the general law significantly. In Queensland the public can inspect any document in a court file, subject to any court order restricting access to the file or document or the file or document being required for the court's use. ${ }^{115}$ In Victoria the public may obtain copies of any document filed in a proceeding except documents which the court has ordered remain confidential, or one which in the opinion of the prothonotary ought to remain confidential to the parties. ${ }^{116}$ In the High Court, most documents may be inspected, but affidavits and exhibits to affidavits which have not been received in evidence in court, and documents containing information disclosing the identity of a person if the disclosure is in any way prohibited, are excluded. ${ }^{117}$ In the Australian Capital Territory, the general principle is that anyone may search the registry for, or take a copy of, any document filed in the registry ${ }^{118}$ but this is qualified in respect of an extensive range of documents which may only be inspected with the court's leave. ${ }^{119} \mathrm{In}$ other jurisdictions the rules of court express in large measure the general law.

United States in Zubalake I, 2003 US Dist Lexis 7939, 2003 WL 21087884 and

Zubalake II, 216 FRD 280; 2003 US Dist Lexis 12643 in relation to how costs of complying with orders for electronic document production should be met.

${ }_{113}$ Titelius v Public Service Appeal Board (1999) 21 WAR 201 at 223, 225.

${ }^{114}$ Australian Securities and Investment Commission v Rich [2002] NSWSC 198.

${ }^{115}$ Uniform Civil Procedure Rules 1999 (Qld) r 981.

${ }^{116}$ Supreme Court (General Civil Procedure) Rules 1996 (Vic) r 28.05.

${ }^{117}$ High Court Rules 2004 (Cth) r 4.07.4.

${ }^{118}$ Court Procedure Rules 2006 (ACT) r 2903(1).

${ }^{119}$ Court Procedure Rules 2006 (ACT) r 2903(2). The documents specified include affidavits that have not been read in court, unsworn statements of evidence, documents that the court has ordered to be kept confidential, and documents that the registrar decides should be confidential to the parties to the proceeding in the interests of justice. 
In Western Australia ${ }^{120}$ and the Federal Court ${ }^{121}$, for example, the rules define the documents in a proceeding that a person may inspect in the Registry, and also those which may not be accessed by a person who is not a party to the proceeding without the leave of the court or registrar. The documents requiring leave before access may be granted include affidavits and unsworn statements of evidence. ${ }^{122}$ In Tasmania a similar situation prevails, and nonparties are not permitted to inspect most documents without the leave of the court. ${ }^{123}$ The position in New South Wales is more restrictive, with access to all material in any proceedings being available only to the parties, except with the leave of the court. ${ }^{124}$

When a trial is proceeding issues of public access to evidentiary material are in the inherent jurisdiction of the trial judge. ${ }^{125}$ If leave is sought based on the principle of open justice factors that will influence the court in the exercise of the discretion include: the extent to which the document has been referred to in open court, the stage reached in the proceedings, the contents of the document, whether access to the document is necessary or desirable for understanding the proceedings, and the purpose for which access is required. ${ }^{126}$

For cases which have attracted significant public attention and are being heard in open court, media interests may well seek to inspect and copy documents from the court file. The court may be expected to grant leave to inspect a filed document which has been relied on in the course of the hearing if that will aid the media interest concerned to understand what has transpired in court, and so to allow informed reporting of the case.

The conduct of a trial electronically presents a range of extra issues to be considered in the context of access to documents. The technology used at trial can include a facility permitting documents to which reference is being made

${ }^{120}$ Rules of the Supreme Court 1979 (WA) O 67 r 11.

${ }^{121}$ Federal Court Rules O 46 r 6.

${ }^{122}$ In the ordinary course expert reports will be exhibited or annexed to affidavits or witness statements and so they are effectively in the same position.

${ }^{123}$ Supreme Court Rules 200 (Tas) r 33. The documents excluded are: any documents relating to proceedings in chambers, affidavits, interrogatories and answers to interrogatories, lists of documents given on discovery, admissions taken on deposition, subpoena or documents lodged in answer to a subpoena, and any document which the registrar considers ought to remain confidential to the parties.

${ }^{124}$ Practice Note SCGen 2 Supreme Court-Access to Court Files, 17.8.05.

${ }^{125}$ Hammond $v$ Scheinberg (2001) 52 NSWLR 49 at 50, 52.

${ }^{126}$ Van Stokkum v Finance Brokers Supervisory Board [2002] WASC 192. 
to be displayed on larger screens that can be viewed by members of the public (including the media).

A regime may be established to deal with documents in respect of which confidentiality orders are in place. It is possible to display documents on the screens available to the judge or to the legal representatives only and not on the public screens. It is also possible to edit statements admitted into evidence so as to exclude material rejected on evidentiary grounds so that when the statements are brought up onto the screens the rejected material does not appear. The ease with which exhibits may be transmitted, however, magnifies the risk that a party will be exposed to publication of confidential or sensitive material that will have no bearing on the outcome of the case as there are considerable practical difficulties facing parties in satisfying themselves that all confidential material has been identified and accommodated by the appropriate confidentiality regime.

The weighing of interests of open justice against the proper protection of confidentiality and other interests of parties involving in proceedings was an issue for consideration in the course of the trial in Seven Network Ltd $v$ News Ltd (No 9). ${ }^{127}$ In that case the Seven Network brought proceedings seeking relief against 22 respondents alleging, inter alia, collusive conduct by most respondents in relation to the bidding rights to Australian Football League and National Rugby League Games. The case was conducted in an electronic court. The electronic document database contained over 75,000 documents. As documents on the database were referred to they were usually brought up on computer screens accessible by the legal representatives and the court, and also on larger screens that could be viewed by members of the public, including the media. A regime had been established to deal with documents that were the subject of confidentiality orders.

Some days into the proceeding (then estimated to run between 6 and 8 months) the Australian Broadcasting Corporation ("ABC"), which was not a party to the proceedings, filed a motion under the Federal Court Rules, O 46 r 6 seeking leave to inspect and have access to all affidavits, witness statements and expert reports in evidence, and also to all exhibits, written submissions and transcript. No access was sought to documents the subject of

127 [2005] FCA 1394 at [4]-[7]. Sackville J further discussed the dimensions of the litigation and the use of the electronic courtroom when delivering judgment after the conclusion of the proceeding: Seven Network Limited $v$ News Limited [2007] FCA 1062 at [6]-[9]. 
an order under s 50 of the Federal Court Act 1976 (Cth) ${ }^{128}$ or any other order for confidentiality.

There was no opposition by the parties to access being given to the ABC (and therefore other media outlets) to the pleadings, those parts of affidavits, witness statements and expert reports admitted into evidence, written submissions and the transcript. The significant dispute related to nonconfidential exhibits which had not been referred to in the course of evidence or oral argument or in written submissions provided to the Court.

For the $\mathrm{ABC}$ it was urged that the principle of open justice required the making of the order sought. Sackville J acknowledged the importance of the principle that the administration of justice must take place in open court ${ }^{129}$ and was satisfied that considerable weight should be given to the principle. ${ }^{130}$ His Honour noted ${ }^{131}$, however, that it was established that open justice is a principle and not a "freestanding right" 132 and it had to be weighed against other principles or policies that needed to be taken into account.

The conduct of an electronic trial was contrasted with the position of a traditional "hard copy" trial. In a traditional trial, public access is usually decided on a document by document basis and there are associated practical constraints of time and cost associated with copying, storing and searching the documentary evidence. On the other hand exhibits may be transmitted through the use of technology at trial with extraordinary ease, and special care is required to protect the legitimate interests of the parties. Sackville J accepted that the sheer volume of documents that had been or would be tendered at trial, and the time frame in which the parties were required to prepare for trial, meant there was a serious risk that some material would be allowed into evidence by default or by error and also that the parties may fail

${ }^{128}$ Section 50 provides that the court may, at any time during or after the hearing of a proceeding in the Court, make such order forbidding or restricting the publication of particular evidence, or the name of a party or witness, as appears to the court to be necessary in order to prevent prejudice to the administration of justice or the security of the Commonwealth.

${ }^{129}$ Authorities to which he referred in relation to the principle of open justice and the rationale for it included: Macquarie Radio Network $v$ The Australian Broadcasting Authority [2002] FCA 1408; $R$ v Davis (1995) 57 FCR 512; Russell v Russell (1976) 134 CLR 495.

${ }^{130}$ [2005] FCA 1394 at [28].

131 [2005] FCA 1394 at [23].

${ }^{132}$ See John Fairfax Publications Pty Ltd $v$ Ryde Local Court [2005] NSWCA 101 at [29] per Spigelman CJ (with whom Mason P and Beazley JA agreed). 
to claim confidentiality in respect of documents for which such a claim could legitimately be made.

Having weighed the competing considerations, Sackville J concluded that the $\mathrm{ABC}$ should have access to exhibits only when they are referred to in the course of evidence or oral argument or in written submissions provided to the Court.

\section{CONCLUSION}

Much progress has been made in recent years in adopting technology for use in the litigation process and it may fairly be said that technology is now wholeheartedly embraced by some practitioners and also by some members of the judiciary.

In cases involving large numbers of documents it is now not uncommon to find that parties are able to reach agreement on the adoption of technology both pre-trial and at trial, although there may be associated issues which remain in dispute. In Seven Network Ltd v News Ltd (No 9) ${ }^{133}$, for example, there was no issue about whether an electronic courtroom should be used, but rather about access to documents transmitted through the use of the technology at trial.

Certainly in cases where it can be shown to be in the interests of justice for a matter to proceed electronically it is clear the courts can and will make appropriate directions, whether or not desired by all parties to the litigation. These will include the use of a technology court for the trial.

In most jurisdictions there are strategies in place to establish electronic courtroom facilities and other services for judges, litigants and their legal representatives, and a number of courtrooms equipped with various technological facilities such as internet access, power points, support for "real time" transcript, and video-conferencing facilities. ${ }^{134}$ The demand for these

${ }_{133}$ Seven Network Ltd $v$ News Ltd (No 9) [2005] FCA 1394.

${ }^{134}$ In most jurisdictions the Supreme Court websites provide information as to the technology available for use or set up in particular courtrooms. See eg :the Supreme Court of Victoria website at http://www.supremecourt.vic.gov.au/CA256CC60028922C/page/Courtroom+Techno logy? OpenDocument\&1=90-Courtroom+Technology $\& 2=\sim \& 3=\sim$ and the Supreme Court of Queensland website at: http://www.courts.qld.gov.au/about/technology.htm. 
facilities will undoubtedly increase. Law graduates are entering the workforce with higher levels of competence in the use of information technology than ever before, and many have specialist knowledge of electronic litigation processes. ${ }^{135}$ In addition the need to deal with disclosure of electronic documents in their native format will undoubtedly force practitioners to embrace the use of technology in the litigation process.

The courts have already begun to consider a range of issues that arise from the use of technology in pre-trial and trial processes. They will need to grapple with many more as the slow but inevitable culture shift in the profession occurs in Australia and the conduct of litigation electronically becomes the norm in everyday litigation practice.

\footnotetext{
${ }^{135}$ A number of Law Schools now have custom-built fully electronic moot courts, including the Queensland University of Technology, Murdoch University, the University of Canberra, and the University of Melbourne. Several, including the Queensland University of Technology and Murdoch University, also offer students specialist units in electronic litigation.
} 
